\title{
Who eats what, where and when? Isotope- labelling experiments are coming of age
}

\author{
Josh D Neufeld ${ }^{1,3}$, Michael Wagner ${ }^{2}$ and J Colin Murrell ${ }^{1}$ \\ ${ }^{1}$ Department of Biological Sciences, University of Warwick, Coventry, UK and ${ }^{2}$ Department of Microbial \\ Ecology, Vienna Ecology Center, University of Vienna, Vienna, Austria
}

\begin{abstract}
Isotope-labelling experiments have changed the way microbial ecologists investigate the ecophysiology of microbial populations and cells in the environment. Insight into the "uncultivated majority' accompanies methodology that involves the incorporation of stable isotopes or radioisotopes into sub-populations of environmental samples. Subsequent analysis of labelled biomarkers of sub-populations with stable-isotope probing (DNA-SIP, RNA-SIP, phospholipidderived fatty acid-SIP) or individual cells with a combination of fluorescence in situ hybridization and microautoradiography reveals linked phylogenetic and functional information about the organisms that assimilated these compounds. Here, we review some of the most recent literature, with an emphasis on methodological improvements to the sensitivity and utility of these methods. We also highlight related isotope techniques that are in continued development and hold promise to transform the way we link phylogeny and function in complex microbial communities.
\end{abstract}

The ISME Journal (2007) 1, 103-110; doi:10.1038/ismej.2007.30; published online 17 May 2007

Keywords: DNA-SIP; FISH-MAR; isotope array; Raman; RNA-SIP; PLFA-SIP

\section{Introduction}

The environment fosters an intricate combination of organisms, nutrients and physical matrices, harbouring almost immeasurable niche diversity. Within this context, microorganisms inhabit every conceivable location on earth, gaining energy by coupling most energetically favourable electron donors and receptors (Schmidt, 2006). Linking the identification of uncultured microorganisms with their potential to metabolize compounds in the environment represents the Holy Grail of scientific discovery for microbial ecologists. The advent of stable- and radioactive-isotope-based techniques was welcomed for the link it provided between the phylogeny and function of uncultivated microbes. Stable-isotope probing (SIP) for use in microbial ecology was based on the premise that a physiologically active subset of organisms within environmental samples, when offered substrates labelled with a stable isotope, would incorporate the heavier C- or N-source into cell components. The first demonstrations of stable-isotope labelled phospholipid-derived fatty acids (PLFA; Boschker et al.,

Correspondence: Professor JC Murrell, Department of Biological Sciences, University of Warwick, Coventry CV4 7AL, UK.

E-mail: j.c.murrell@warwick.ac.uk

${ }^{3}$ Address from 1 July 2007: Department of Biology, University of Waterloo, Waterloo, Ontario, Canada N2L 3G1.

Received 26 March 2007; revised 28 March 2007; accepted 28 March 2007; published online 17 May 2007
1998), DNA (Radajewski et al., 2000) and RNA (Manefield et al., 2002) established the method for clear identification of specific sub-populations of microorganisms that metabolized specific compounds. The parallel development of the fluorescence in situ hybridization and microautoradiography (FISH-MAR) technique (Lee et al., 1999) offered microbial ecologists the ability to directly observe the incorporation of substrates labelled with a radioactive isotope into single microbial cells. Over the past few years, dedicated research in many laboratories has refined earlier SIP and FISH-MAR methodology by reducing bias, increasing sensitivity and expanding the applications of isotope studies (multiple environments, substrates and target organisms). Related techniques are rapidly being developed and gaining in applicability. For example, isotope arrays, Raman microscopy and nanoSIMS are all expanding our suite of isotope-based techniques. Here, we highlight recent and notable achievements, including up-and-coming developments that are set to transform the way we study the phylogeny and function of microbes in the biosphere.

\section{Stable-isotope probing}

SIP experiments are dependent upon the availability of suitable stable isotopes of atoms (for example, ${ }^{13} \mathrm{C}$, ${ }^{15} \mathrm{~N},{ }^{18} \mathrm{O}$ ), and access to target compounds which are fully, or significantly, substituted with the stable isotope of choice. The earliest PLFA-SIP and DNA- 
SIP studies focused on one-carbon $\left(\mathrm{C}_{1}\right)$ metabolism in sediments and soils (Boschker et al., 1998; Radajewski et al., 2000), but SIP studies have now diversified to include a wide range of substrates and environments (reviewed by Dumont and Murrell, 2005; Evershed et al., 2006; Friedrich, 2006; Madsen, 2006; Whiteley et al., 2006). In fact, a sampling of the most recent literature highlights the diverse extent to which substrates and environments are being coupled. Examples include ${ }^{13} \mathrm{C}$-labelled acetate in Israel's Lake Kinneret (Schwarz et al., 2007) and in the Florida Everglades (Chauhan and Ogram, 2006), cellulose in an agricultural soil (el Zahar Haichar et al., 2007), benzene in contaminated groundwater (Kasai et al., 2006), organic substrates in marine sediments (Webster et al., 2006), atmospheric methane in an upland soil (Maxfield et al., 2006), 2,4-dichlorophenoxyacetic acid in a field soil (Cupples and Sims, 2007), pyrene in a soil bioreactor (Singleton et al., 2006), bicarbonate in an estuarine sediment (Freitag et al., 2006), propionate in a wastewater bioreactor (Meyer et al., 2006), acetate/methanol in activated sludge (Osaka et al., 2006) and wheat residue in soil (Bernard et al., 2007). For most of these studies, $>99 \%$ fully ${ }^{13} \mathrm{C}$ labelled substrates were purchased from commercial suppliers. However, limited commercial availability of ${ }^{13} \mathrm{C}$ - or ${ }^{15} \mathrm{~N}$-labelled molecules suitable as microbial growth substrates constrains the design of isotope experiments. As a result, several research groups have pioneered in-house chemical and biological synthesis for the preparation of their desired substrates. Singleton et al. (2005, 2006) employed chemical synthesis of commercially unavailable ${ }^{13} \mathrm{C}$-labelled salicylate, naphthalene, phenanthrene and pyrene from the 'building blocks' of purchased ${ }^{13} \mathrm{C}$-phenol, succinic acid and phenol. In a recent study of soil cellulolytic bacteria, the ${ }^{13} \mathrm{C}$ labelled cellulose was purified from the growth medium of Acetobacter xylinus, which was grown on ${ }^{13} \mathrm{C}$-glucose as a sole source of carbon (el Zahar Haichar et al., 2007). Finally, ${ }^{13} \mathrm{CO}_{2}$-labelling of plants represents a clever approach to tracking plant-derived carbon to microorganisms in the rhizosphere (Cadisch et al., 2005; Lu and Conrad, 2005; Rangel-Castro et al., 2005). Such creative chemical and biological synthesis of complex organic compounds widens the application and versatility of SIP.

One of the challenges of SIP experiments is employing substrate concentrations and incubation times that mirror the in situ conditions found in the natural environment. The high sensitivity of PLFASIP helps realize this goal, but for RNA-SIP and DNA-SIP, the synthesis of labelled nucleic acid must be sufficient for the separation and detection of labelled molecules from the abundant background of unlabelled material (reviewed by Neufeld et al., 2007a). Recent developments have increased the sensitivity of the nucleic acid-based SIP technique. In particular, fractionation of cesium chloride or cesium trifluoroacetate gradients (Lueders et al., 2004) enables the objective recovery of nucleic acids and for DNA-SIP, circumvents the visualization of large quantities of unlabelled and labelled DNA with ethidium bromide (Radajewski et al., 2000). Further, purification of low amounts of DNA from gradient fractions is inefficient, but this shortcoming has been overcome by the addition of labelled archaeal DNA (Gallagher et al., 2005) or glycogen (Neufeld et al., 2007b) as carriers for precipitation.

Metagenomic analysis of labelled DNA is one desired goal of current DNA-SIP studies (Dumont et al., 2006). But herein lies the dilemma: incubate samples with near in situ conditions and generate low nanogram yields of labelled DNA or incubate samples with unrealistic substrate concentrations and incubation times, generating microgram yields of labelled DNA for direct cloning? For some studies, so little is known about the organisms and genes involved in metabolizing a particular substrate that any relevant genetic information is a significant discovery; incubation conditions are less important. However, a likely outcome is that with excessive substrate and incubation times, characterized organisms will be similar to those previously identified with cultivation-based approaches. One strong possibility for future innovation is the ability to couple low substrate incubations, $\varphi 29$-based whole-genome amplification of labelled DNA and metagenomics analysis. The major hurdle to overcome will involve balancing the cloning of large DNA fragments with the associated limitation of chimeric artefacts that are generated by cloning genome-amplified DNA (Zhang et al., 2006).

The traditional SIP technique has been tweaked and modified to enable a suite of novel applications and experiments. One recent advance has involved improvements to the labelling and detection of DNA using ${ }^{15} \mathrm{~N}$-labelled substrates (Cadisch et al., 2005). The resolution of labelled and unlabelled DNA (or RNA) following ${ }^{15} \mathrm{~N}$ incorporation is less than that for ${ }^{13} \mathrm{C}$ incorporation (Cupples et al., 2006), reflecting the differential abundance of nitrogen and carbon in DNA, respectively. Buckley et al. (2007b) have demonstrated a unique approach to disentangle the parallel effects of $\mathrm{G}+\mathrm{C}$ content and isotopic enrichment on isopycnic separation of DNA. Through a combination of two ultracentrifugation steps and the addition of an intercalating compound to the second ultracentrifugation, ${ }^{15} \mathrm{~N}$-labelled DNA is effectively separated from high $\mathrm{G}+\mathrm{C}$ unlabelled DNA. The utility of such an approach was demonstrated by the discovery of uncultured and putatively novel nitrogen-fixing bacteria in the Alphaproteobacteria (Rhodoplanes), Betaproteobacteria and Actinobacteria (Buckley et al., 2007a).

Expanding on the stable isotopes molecules available for nucleic acid-based SIP, Schwartz (2007) recently demonstrated the utility of stable oxygen $\left({ }^{18} \mathrm{O}\right)$ for DNA-SIP. DNA and RNA may be labelled efficiently with ${ }^{18} \mathrm{O}$ because of the five 
oxygen atoms per nucleotide in the sugar backbone of DNA, in addition to the two neutrons offered by each incorporated molecule of stable oxygen. Incubating Escherichia coli cultures or soil samples with $\mathrm{H}_{2}^{18} \mathrm{O}$ yielded DNA from actively growing cells that was sufficiently labelled to separate ${ }^{18} \mathrm{O}$ containing DNA from a background of ${ }^{18} \mathrm{O}$-DNA. Such an approach offers a substrate-independent ability to characterize active community members and will be particularly helpful in examining the impact of moisture content on soil microbial communities (Schwartz, 2007).

An often-cited disadvantage of SIP-based studies is that biomarkers from organisms that can feed on metabolic degradation products of other organisms may become labelled during an SIP incubation. Cross-feeding is a lingering explanation for the puzzling observation of labelled DNA possessing an Acidobacteria 16S ribosomal RNA (rRNA) gene sequence after a soil methanol incubation in the original DNA-SIP publication (Radajewski et al., 2000). Regardless of this, what has been a common criticism, that is, 'cross-feeding' can now be turned into an advantage to look at the flow of carbon through ecosystems. For several SIP experiments, studying trophic networks was performed by labelling macroorganisms that provide nutrients for a natural microbial community (Cadisch et al., 2005; $\mathrm{Lu}$ and Conrad, 2005; Rangel-Castro et al., 2005) or by labelling microbial cells. Lueders et al. (2006) recently conducted a cross-feeding study by supplementing indigenous soil microbial communities with an excess of ${ }^{13} \mathrm{C}$-labelled $E$. coli cells. An important consideration was that the soil communities were monitored over time, revealing a complex trophic network, including the labelling of rRNA gene sequences associated with gliding micropredators.

Near-future SIP developments will likely include its combination with phylochips for highly parallel analyses of the community composition represented by the heavy DNA or rRNA (Wagner et al., 2007) and the long-awaited advent of mRNA-SIP and polypeptide-SIP. The current DNA-SIP protocol (Neufeld et al., 2007b) does not directly implicate the expression of genes that are associated with labelled DNA. The RNA-SIP protocol (Whiteley et al., 2007) focusses on 16S rRNA and does not capture mRNA. There is no questioning the value of retrieving expressed genes (that is, mRNA) or synthesized polypeptides from the environment, which are involved in growth on a particular compound. Once these methods are developed and optimized, we anticipate that both mRNA-SIP and polypeptide-SIP will serve as sensitive and powerful tools, assisting in novel environmental gene discovery and complementing experiments that use RNA-SIP and DNA-SIP.

SIP-based studies have largely focussed on the discovery of taxonomic and functional gene sequences associated with labelled nucleic acid.
Understandably, the environments and substrates being examined yield surprising glimpses into organisms involved in substrate metabolism. A few examples include the possible involvement of Acidobacteria in methanol metabolism (Radajewski et al., 2000), a possible role for Betaproteobacteria in $\mathrm{CH}_{4}$ oxidation (Morris et al., 2002), the implication of a Thauera sp. in phenol degradation (Manefield et al., 2002), and the role of methanogenic Archaea in consuming plant exudates (Lu and Conrad, 2005). However, SIP experiments offer more than an insight into unknown and uncultured contributors to substrate metabolism. Importantly, the retrieval and characterization of sequences belonging to extant cultured isolates and characterized strains suggests that the organisms we study in the laboratory are involved in relevant processes in the natural environment. As the use of SIP in microbial ecology increases, we anticipate a shift from discovery-driven science to hypothesis-testing experimentation. The questions SIP may be used to answer will gradually shift from 'who eats what?' to 'who eats what, where and when?'. Instead of simply determining which organisms consume a specific substrate in a particular soil, we anticipate that the effects of $\mathrm{pH}$, depth, latitude, altitude or temperature on active microbes will be elucidated. Such experiments would be best served by carrying out SIP alongside ecosystem process measurements, demonstrating the relevance of substrate concentrations and metabolic rates while identifying and characterizing functionally relevant microorganisms. With substantial research interest focussed on climate change, ecosystem loss and human health, linking active organisms with their preferred C- and N-sources will remain a strong research incentive in microbial ecology, one for which SIP can play an ever-expanding role.

\section{FISH-MAR}

The adoption of FISH for microbial ecology involved the use of $16 \mathrm{~S}$ or 23S rRNA-targeted gene probes to detect single microbial cells from within a complex microbial community (reviewed by Wagner et al., 2003). This enabled image analysis-assisted quantification of microbes in the environment (Daims et al., 2006) and the visualization of cells relative to one another, revealing information about spatial structuring and physical interactions that occur in highly aggregated environments, such as biofilms (Gieseke et al., 2001) and activated sludge flocs (Maixner et al., 2006). By quickly exposing an environmental sample to a low dose of radioactively labelled substrate, slides prepared for FISH analysis can also be used to expose an autoradiographic emulsion for several days, causing silver grains to form in areas immediately adjacent to radioactive cells. Now referred to as FISH-MAR, this approach, which requires much shorter incubation times than 
DNA-SIP, was first demonstrated in 1999 (Lee et al., 1999; Ouverney and Fuhrman, 1999). Since then, FISH-MAR has provided many direct cultivationindependent links between the phylogeny and function of individual microbial cells in various natural and man-made ecosystems (reviewed by Wagner et al., 2006). At present, FISH-MAR can target up to seven different bacterial populations (Amann et al., 1996), uses 'hierarchical' probe combinations to reduce the possibility of falsepositive signals (Loy et al., 2007) and has an optical resolution of $0.5-2 \mu \mathrm{m}$ (Nielsen et al., 2003b), ideal for individual microbial cells. Further, the number of silver grains formed adjacent to individual cells provides a quantitative estimate of the contributions of different cells to substrate metabolism (Nielsen et al., 2003a). In oligotrophic environments, physiologically active cells may contain low rRNA copy numbers and be undetectable with standard FISH techniques. This limitation can be overcome by use of catalysed reporter deposition with horseradish peroxidase-labelled probes (CARD-FISH), which can also be combined with MAR (MICRO-CARD-FISH) (Sintes and Herndl, 2006). Recently, the uptake of radiolabelled substrate into FISH-identified bacterial populations was monitored by beta microimaging instead of MAR (Gieseke et al., 2005). This elegant approach offers quantitative data without the need of counting silver grains, but suffers from a relatively low spatial resolution of about $10 \mu \mathrm{m}$, which is above the single-cell level. Therefore, this technique is currently only suitable for application to wellstructured microbial communities like those found in biofilms (Gieseke et al., 2005), microbial mats and anaerobic granules (Collins et al., 2005).

A strength of FISH-MAR is that the detection of labelled substrate incorporation does not rely on a specific biomarker. This feature increases the sensitivity of the approach and enables the detection of certain physiological activities, like the incorporation of added substrate into intracellular storage compounds (Wagner and Loy, 2002), which cannot be monitored with SIP techniques. On the other hand, FISH-MAR is limited by the availability and affordability of radiolabelled substrates. As with SIP, synthesizing complex organic compounds is challenging and requires safety precautions, because of the radioactive label. Alternatively, heterotrophic growth can be studied by incubating environmental samples with an unlabelled substrate in the presence of ${ }^{14} \mathrm{CO}_{2}$ (Hesselsoe et al., 2005). Because heterotrophic organisms assimilate $\mathrm{CO}_{2}$ during growth under aerobic and anaerobic conditions, this approach (HetCO ${ }_{2}$-MAR) is affordable and has the convenience of using the same labelled compound for assessing growth on multiple substrates. Such an approach has been demonstrated for pure cultures and filamentous 'Candidatus Microthrix parvicella' in activated sludge under different electron donor/ acceptor combinations (Hesselsoe et al., 2005). If $\mathrm{HetCO}_{2}$-MAR is used as a discovery tool, it is important to remember that not only heterotrophic substrate-consuming but also all active autotrophic microorganisms will be labelled. The latter can be avoided by addition of specific inhibitors (Wagner et al., 2006).

Drawbacks of FISH-MAR are its restriction to environments amenable to FISH and a requirement for some prior empirical knowledge of the organisms that are likely to assimilate a radioactively labelled carbon source. Without specific probes targeting active populations, only higher level phylogenetic assignments (for example, by using the ever-expanding collection of phyla-specific probes; Loy et al., 2007) of the detected radioactive cells may be possible. To achieve higher phylogenetic resolution, SIP has been used to complement FISH-MAR by identifying putative key players before identifying active populations on an individual cell basis. Combining SIP with FISH-MAR has thus far been demonstrated with denitrifying communities in wastewater that use methanol or acetate as carbon sources (Ginige et al., 2004, 2005). In both cases, probes designed against predominant phylotypes in the ${ }^{13} \mathrm{C}$-labelled SIP DNA successfully targeted radioactive cells with FISH-MAR. These results support SIP as a method for identifying environmentally relevant phylotypes and highlight the utility of combining SIP and FISH-MAR for linking phylogeny and function in a focussed and logical approach.

If dealing with uncultured microorganisms, microbial ecologists, in most cases, use the 16S rRNA gene to classify diversity and to define units, which can be specifically recognized with molecular tools like oligonucleotide probes or PCR-primers (reviewed by Neufeld and Mohn, 2005). However, genomics and environmental metagenomics data have revealed pronounced differences in gene content of microbial strains which share identical 16S rRNA gene sequences (Konstantinidis et al., 2006) and even genomically identically strains might show dramatic differences in protein composition and physiological activity in the various microniches of an environmental sample. As a single-cell tool, MAR-FISH can decipher such ecophysiological heterogeneity within rRNA sequence types and offers in parallel spatial information on the arrangement of the individual cells relative to other community members and to abiotic environmental components. We expect that this combined information will enable microbial ecologists in the future to tackle key questions on how abiotic and biotic interactions influence the ecophysiology of individual microbial cells.

\section{The isotope array}

The isotope array is a powerful method that offers a level of throughput not readily afforded by FISH-MAR or SIP techniques (Adamczyk et al., 
2003) and should become a useful tool for any environment that yields sufficient RNA for direct hybridization. After incubating samples with a radioactive substrate, RNA is extracted, fluorescently labelled and hybridized to rRNA probes in a microarray format. Subsequently, the microarray is analysed with a fluorescence scanner and beta microimager to reveal microbial community composition and to identify substrate-consuming community members, respectively. The applicability of this approach to complex samples was shown by Adamczyk et al. (2003) who designed a simple prototype array to monitor ${ }^{14} \mathrm{C}$-bicarbonate incorporation into the lithoautotrophic ammonia-oxidizers of activated sludge. They indicated that the main advantages of the isotope array was the direct detection of labelled RNA from active organisms, without the potential to detect unlabelled background as can occur with DNA- and RNA-SIP. For exploiting the full potential of the isotope array approach, it would be best combined with encompassing phylochips (Loy et al., 2005) or even highdensity DNA microarrays (Brodie et al., 2007), but at least the latter option will have to await the development of beta microimagers with higher spatial resolution. However, even if microarrays with larger spot sizes are applied, the isotope array approach should be ideally suited to decipher microbial food webs in complex microbial communities by performing experiments at different time points after incubation of the sample with the labelled substrate.

\section{Other techniques in development}

Raman microscopy and its combination with FISH

Raman confocal microscopy employs an excitation laser incident on samples to measure the vibrational energy of chemical bonds. The scattered laser light is captured by a charge-coupled device camera, and a spectrum is obtained that has discernable peaks for different biological molecules in the cell. When tested on single microbial cells, the peaks in the Raman spectra corresponding to phenylalanine, proteins and nucleic acids were 'red-shifted' by the incorporation of ${ }^{13} \mathrm{C}$-labelled substrate (Huang et al., 2004). The magnitude of this red shift was independent of bacterial species tested and corresponded to the proportion of label. Nucleic acids with only $20 \%{ }^{13} \mathrm{C}$ incorporation were clearly discernable from $100 \%{ }^{12} \mathrm{C}$-fed cells (Huang et al., 2007). As the optical resolution of Raman microscopy $(\sim 1 \mu \mathrm{m})$ is similar to that of FISH, the two methods are conceivably complementary. As Raman microscopy detects stable-isotope incorporation into cellular constituents, this would offer a possible advantage over FISH-MAR by obviating the need to handle radioisotopes and facilitates the somewhat cumbersome quantification of silver grains. Furthermore and in contrast to FISH-MAR, Raman provides information into which cellular compounds the labelled substrate was incorporated. Recently, FISH and Raman confocal microscopy have been directly combined to confirm the involvement of Pseudomonas spp. in the assimilation of ${ }^{13} \mathrm{C}_{10}$-naphthalene in groundwater (Huang et al., 2007).

\section{Stable-isotope mass spectrometry}

Multi-isotope imaging mass spectrometry (or nanoSIMS) is conceptually similar to the approach of Raman confocal microscopy. It improves upon the earlier secondary ion mass spectrometry (SIMS) technology, which was originally coupled with FISH (Orphan et al., 2001), but at only low resolution $(\sim 10-15 \mu \mathrm{m})$. The nanoSIMS technology analyses the stable- or radioactive-isotope content of single cells at a resolution $(50 \mathrm{~nm})$ that exceeds a Raman microscope, possesses sensitivity in cellular ${ }^{14} \mathrm{C}$ detection that exceeds MAR by $1000 \times$, has a stable-isotope measurement precision of $\pm 1 \%$, and a price ( $>£ 1300000$ ) to match its impressive performance (Kuypers and Jørgensen, 2007). As already achieved for Raman-FISH, a combination of FISH-nanoSIMS would enable phylogenetic and isotopic analysis of an environmental sample in a single scan. Furthermore, it might even become possible to couple isotope array experiments, performed after the addition of stableisotope labelled substrates, with nanoSIMS. Such an exciting combination would provide highthroughput, stable-isotope-based analysis of microbial communities and their functions. Owing to the high spatial resolution of nanoSIMS, these analyses could possibly be performed in a massively parallel manner with high-density arrays. Microbial ecologists will need patience for nanoSIMS instruments to become commonplace and affordable, but with unparalleled versatility, quantification and sensitivity (Lechene et al., 2006), the potential looms large.

\section{Conclusions}

Isotope-based techniques have become firmly established in international microbial ecology research. Their relative ease-of-use and unparalleled ability to link the structure and function of uncultivated organisms enables long unanswered questions to be addressed with creative experimentation. As discovery science becomes increasingly complemented with hypothesis-driven research, we anticipate learning vastly more about who eats what, where and when. Microbial communities are foundational to almost all aspects of nutrient cycling in the natural environment. Learning more about the metabolic contributions of bacteria, Archaea and microbial Eukarya will shed increasingly more light on their behaviour as single cells, populations and communities. As microbial ecologists focus on 
issues of global importance, we anticipate that isotopic techniques can and will continue to catalyse good science and innovative research.

\section{Acknowledgements}

This work was supported by funding from the Natural Environment Research Council (United Kingdom). JDN also acknowledges support from the Natural Sciences and Engineering Research Council (Canada). MW was supported by the Vienna Science and Technology Fund (WWTF) and the Austrian Science Fund (FWF).

\section{References}

Adamczyk J, Hesselsoe M, Iversen N, Horn M, Lehner A, Nielsen PH et al. (2003). The isotope array, a new tool that employs substrate-mediated labeling of rRNA for determination of microbial community structure and function. Appl Environ Microbiol 69: 6875-6887.

Amann R, Snaidr J, Wagner M, Ludwig W, Schleifer KH. (1996). In situ visualization of high genetic diversity in a natural microbial community. J Bacteriol 178: 3496-3500.

Bernard L, Mougel C, Maron P-A, Nowak V, Lévêque J, Henault C et al. (2007). Dynamics and identification of soil microbial populations actively assimilating carbon from ${ }^{13} \mathrm{C}$-labelled wheat residue as estimated by DNA- and RNA-SIP techniques. Environ Microbiol 9: $752-764$.

Boschker JT, Nold SC, Wellsbury P, Bos D, de Graaf W, Pel R et al. (1998). Direct linking of microbial populations to specific biogeochemical processes by ${ }^{13} \mathrm{C}$-labelling of biomarkers. Nature 392: 801-805.

Brodie EL, DeSantis TZ, Parker JPM, Zubietta IX, Piceno YM, Andersen GL. (2007). Urban aerosols harbor diverse and dynamic bacterial populations. Proc Nalt Acad Sci USA 104: 299-304.

Buckley DH, Huangyutitham V, Hsu S-F, Nelson TA. (2007a). Stable isotope probing with ${ }^{15} \mathrm{~N}_{2}$ reveals novel non-cultivated diazotrophs in soil. Appl Environ Microbiol [E-pub ahead of print]; doi:10.1128/AEM. 02610-06.

Buckley DH, Huangyutitham V, Hsu S-F, Nelson TA. (2007b). Stable isotope probing with ${ }^{15} \mathrm{~N}$ achieved by disentangling the effects of genome $\mathrm{G}+\mathrm{C}$ content and isotope enrichment on DNA density. Appl Environ Microbiol [E-pub ahead of print]; doi:10.1128/AEM. 02609-06.

Cadisch G, Espana M, Causey R, Richter M, Shaw E, Morgan JAW et al. (2005). Technical considerations for the use of ${ }^{15} \mathrm{~N}$-DNA stable-isotope probing for functional microbial activity in soils. Rapid Commun Mass Spectrom 19: 1424-1428.

Chauhan A, Ogram A. (2006). Phylogeny of acetateutilizing microorganisms in soils along a nutrient gradient in the Florida Everglades. Appl Environ Microbiol 72: 6837-6840.

Collins G, O’Connor L, Mahony T, Gieseke A, de Beer D, O'Flaherty V. (2005). Distribution, localization, and phylogeny of abundant populations of Crenarchaeota in anaerobic granular sludge. Appl Environ Microbiol 71: 7523-7527.
Cupples AM, Shaffer EA, Chee-Sanford JC, Sims GK. (2006). DNA buoyant density shifts during ${ }^{15} \mathrm{~N}-\mathrm{DNA}$ stable isotope probing. Microbiol Res [E-pub ahead of print]; doi:10.1016/j.micres.2006.01.016.

Cupples AM, Sims GK. (2007). Identification of in situ 2,4-dichlorophenoxyacetic acid-degrading soil microorganisms using DNA-stable isotope probing. Soil Biol Biochem 39: 232-238.

Daims H, Lücker S, Wagner M. (2006). Daime, a novel image analysis program for microbial ecology and biofilm research. Environ Microbiol 8: 200-213.

Dumont M, Murrell J. (2005). Stable isotope probing linking microbial identity to function. Nat Rev Microbiol 3: 499-504.

Dumont MG, Radajewski SM, Miguez CB, McDonald IR, Murrell JC. (2006). Identification of a complete methane monooxygenase operon from soil by combining stable isotope probing and metagenomic analysis. Environ Microbiol 8: 1240-1250.

el Zahar Haichar F, Achouak W, Christen R, Heulin T, Marol C, Marais M-F et al. (2007). Identification of cellulolytic bacteria in soil by stable isotope probing. Environ Microbiol 9: 625-634.

Evershed RP, Crossman ZM, Bull ID, Mottram H, Dungait JAJ, Maxfield PJ et al. (2006). ${ }^{13} \mathrm{C}$-Labelling of lipids to investigate microbial communities in the environment. Curr Opin Biotechnol 17: 72-82.

Freitag TE, Chang L, Prosser JI. (2006). Changes in the community structure and activity of betaproteobacterial ammonia-oxidizing sediment bacteria along a freshwater-marine gradient. Environ Microbiol 8: 684-696.

Friedrich MW. (2006). Stable-isotope probing of DNA: insights into the function of uncultivated microorganisms from isotopically labeled metagenomes. Curr Opin Biotechnol 17: 59-66.

Gallagher E, McGuinness L, Phelps C, Young LY, Kerkhof LJ. (2005). ${ }^{13} \mathrm{C}$-Carrier DNA shortens the incubation time needed to detect benzoate-utilizing denitrifying bacteria by stable-isotope probing. Appl Environ Microbiol 71: 5192-5196.

Gieseke A, Nielsen JL, Amann R, Nielsen PH, de Beer D. (2005). In situ substrate conversion and assimilation by nitrifying bacteria in a model biofilm. Environ Microbiol 7: 1392-1404.

Gieseke A, Purkhold U, Wagner M, Amann R, Schramm A. (2001). Community structure and activity dynamics of nitrifying bacteria in a phosphate-removing biofilm. Appl Environ Microbiol 67: 1351-1362.

Ginige MP, Hugenholtz P, Daims H, Wagner M, Keller J, Blackall LL. (2004). Use of stable-isotope probing, full-cycle rRNA analysis, and fluorescence in situ hybridization-microautoradiography to study a methanolfed denitrifying microbial community. Appl Environ Microbiol 70: 588-596.

Ginige MP, Keller J, Blackall LL. (2005). Investigation of an acetate-fed denitrifying microbial community by stable isotope probing, full-cycle rRNA analysis, and fluorescent in situ hybridization-microautoradiography. Appl Environ Microbiol 71: 8683-8691.

Hesselsoe M, Nielsen JL, Roslev P, Nielsen PH. (2005). Isotope labeling and microautoradiography of active heterotrophic bacteria on the basis of assimilation of ${ }^{14} \mathrm{CO}_{2}$. Appl Environ Microbiol 71: 646-655.

Huang WE, Griffiths RI, Thompson IP, Bailey MJ, Whiteley AS. (2004). Raman microscopic analysis of single microbial cells. Anal Chem 76: 4452-4458. 
Huang WE, Stoecker K, Griffiths R, Newbold L, Daims H, Whiteley AS et al. (2007). Raman-FISH: Combining stable-isotope Raman spectroscopy and fluorescence in situ hybridization for the single cell analysis of identity and function. Environ Microbiol (in press).

Kasai Y, Takahata Y, Manefield M, Watanabe K. (2006). RNA-based stable isotope probing and isolation of anaerobic benzene-degrading bacteria from gasolinecontaminated groundwater. Appl Environ Microbiol 72: 3586-3592.

Konstantinidis KT, Ramette A, Tiedje JM. (2006). Toward a more robust assessment of intraspecies diversity, using fewer genetic markers. Appl Environ Microbiol 72: 7286-7293.

Kuypers MMM, Jørgensen BB. (2007). The future of singlecell environmental microbiology. Environ Microbiol 9: 6-7.

Lechene C, Hillion F, McMahon G, Benson D, Kleinfeld A, Kampf JP et al. (2006). High-resolution quantitative imaging of mammalian and bacterial cells using stable isotope mass spectrometry. J Biol 5: 20.

Lee N, Nielsen PH, Andreasen KH, Juretschko S, Nielsen JL, Schleifer KH et al. (1999). Combination of fluorescent in situ hybridization and microautoradiography - a new tool for structure-function analyses in microbial ecology. Appl Environ Microbiol 65: 1289-1297.

Loy A, Maixner F, Wagner M, Horn M. (2007). probeBasean online resource for rRNA-targeted oligonucleotide probes: new features 2007. Nucleic Acids Res 35: D800-D804.

Loy A, Schulz C, Luecker S, Schoepfer-Wendels A, Stoecker K, Baranyi C et al. (2005). 16S rRNA genebased oligonucleotide microarray for environmental monitoring of the betaproteobacterial order 'Rhodocyclales'. Appl Environ Microbiol 71: 1373-1386.

Lu Y, Conrad R. (2005). In situ stable isotope probing of methanogenic Archaea in the rice rhizosphere. Science 309: 1088-1090.

Lueders T, Kindler R, Miltner A, Friedrich MW, Kaestner M. (2006). Identification of bacterial micropredators distinctively active in a soil microbial food web. Appl Environ Microbiol 72: 5342-5348.

Lueders T, Manefield M, Friedrich MW. (2004). Enhanced sensitivity of DNA- and rRNA-based stable isotope probing by fractionation and quantitative analysis of isopycnic centrifugation gradients. Environ Microbiol 6: $73-78$.

Madsen EL. (2006). The use of stable isotope probing techniques in bioreactor and field studies on bioremediation. Curr Opin Biotechnol 17: 92-97.

Maixner F, Noguera DR, Anneser B, Stoecker K, Wegl G, Wagner $M$ et al. (2006). Nitrite concentration influences the population structure of Nitrospira-like bacteria. Environ Microbiol 8: 1487-1495.

Manefield M, Whiteley AS, Griffiths RI, Bailey MJ. (2002). RNA stable isotope probing, a novel means of linking microbial community function to phylogeny. Appl Environ Microbiol 68: 5367-5373.

Maxfield PJ, Hornibrook ER, Evershed RP. (2006). Estimating high-affinity methanotrophic bacterial biomass, growth, and turnover in soil by phospholipid fatty acid ${ }^{13} \mathrm{C}$ labeling. Appl Environ Microbiol 72: 3901-3907.

Meyer RL, Saunders AM, Blackall LL. (2006). Putative glycogen-accumulating organisms belonging to the Alphaproteobacteria identified through rRNA-based stable isotope probing. Microbiol 152: 419-429.
Morris SA, Radajewski S, Willison TW, Murrell JC. (2002). Identification of the functionally active methanotroph population in a peat soil microcosm by stable-isotope probing. Appl Environ Microbiol 68: 1446-1453.

Neufeld JD, Dumont MG, Vohra J, Murrell JC. (2007a). Methodological considerations for the use of stable isotope probing in microbial ecology. Microb Ecol [E-pub ahead of print]; doi:10.1007/s00248-006-9125-x.

Neufeld JD, Mohn WW. (2005). Assessment of microbial phylogenetic diversity based on environmental nucleic acids. In: Stackebrandt E (ed). Molecular Identification, Systematics, and Population Structure of Prokaryotes. Springer-Verlag: Heidelberg, pp 219-260.

Neufeld JD, Vohra J, Dumont MG, Lueders T, Manefield M, Friedrich MW et al. (2007b). DNA stable-isotope probing. Nat Protocols 2: 860-866.

Nielsen JL, Christensen D, Kloppenborg M, Nielsen PH. (2003a). Quantification of cell-specific substrate uptake by probe-defined bacteria under in situ conditions by microautoradiography and fluorescence in situ hybridization. Environ Microbiol 5: 202-211.

Nielsen JL, Wagner M, Nielsen PH. (2003b). Use of microautoradiography to study in situ physiology of bacteria in biofilms. Rev Environ Sci Biotechnol V 2: 261-268.

Orphan VJ, House CH, Hinrichs K-U, McKeegan KD, DeLong EF. (2001). Methane-consuming Archaea revealed by directly coupled isotopic and phylogenetic analysis. Science 293: 484-487.

Osaka T, Yoshie S, Tsuneda S, Hirata A, Iwami N, Inamori Y. (2006). Identification of acetate- or methanol-assimilating bacteria under nitrate-reducing conditions by stableisotope probing. Microb Ecol 52: 253-266.

Ouverney CC, Fuhrman JA. (1999). Combined microautoradiography-16S rRNA probe technique for determination of radioisotope uptake by specific microbial cell types in situ. Appl Environ Microbiol 65: $1746-1752$

Radajewski S, Ineson P, Parekh N, Murrell J. (2000). Stable-isotope probing as a tool in microbial ecology. Nature 403: 646-649.

Rangel-Castro JI, Killham K, Ostle N, Nicol GW, Anderson IC, Scrimgeour CM et al. (2005). Stable isotope probing analysis of the influence of liming on root exudate utilization by soil microorganisms. Environ Microbiol 7: 828-838.

Schmidt T. (2006). The maturing of microbial ecology. Int Microbiol 9: 217-223.

Schwartz E. (2007). Characterization of growing microorganisms in soil through stable isotope probing with $\mathrm{H}_{2}^{18} \mathrm{O}$. Appl Environ Microbiol 73: 2541-2546.

Schwarz JI, Lueders T, Eckert W, Conrad R. (2007). Identification of acetate-utilizing Bacteria and Archaea in methanogenic profundal sediments of Lake Kinneret (Israel) by stable isotope probing of rRNA. Environ Microbiol 9: 223-237.

Singleton DR, Powell SN, Sangaiah R, Gold A, Ball LM, Aitken MD. (2005). Stable-isotope probing of bacteria capable of degrading salicylate, naphthalene, or phenanthrene in a bioreactor treating contaminated soil. Appl Environ Microbiol 71: 1202-1209.

Singleton DR, Sangaiah R, Gold A, Ball LM, Aitken MD. (2006). Identification and quantification of uncultivated Proteobacteria associated with pyrene degradation in a bioreactor treating PAH-contaminated soil. Environ Microbiol 8: 1736-1745. 
Sintes E, Herndl GJ. (2006). Quantifying substrate uptake by individual cells of marine bacterioplankton by catalyzed reporter deposition fluorescence in situ hybridization combined with microautoradiography. Appl Environ Microbiol 72: 7022-7028.

Wagner M, Horn M, Daims H. (2003). Fluorescence in situ hybridisation for the identification and characterisation of prokaryotes. Curr Opin Microbiol 6: 302-309.

Wagner M, Loy A. (2002). Bacterial community composition and function in sewage treatment systems. Curr Opin Biotechnol 13: 218-227.

Wagner M, Nielsen PH, Loy A, Nielsen JL, Daims H. (2006). Linking microbial community structure with function: fluorescence in situ hybridization-microautoradiography and isotope arrays. Curr Opin Biotechnol 17: 83-91.

Wagner M, Smidt H, Loy A, Zhou J. (2007). Unravelling microbial communities with DNA-microarrays: challenges and future directions. Microb Ecol [E-pub ahead of print]; doi:10.1007/s00248-006-9197-7.

Webster G, Watt LC, Rinna J, Fry JC, Evershed RP, Parkes RJ et al. (2006). A comparison of stable-isotope probing of DNA and phospholipid fatty acids to study prokaryotic functional diversity in sulfate-reducing marine sediment enrichment slurries. Environ Microbiol 8: 1575-1589.

Whiteley AS, Manefield M, Lueders T. (2006). Unlocking the 'microbial black box' using RNA-based stable isotope probing technologies. Curr Opin Biotechnol 17: $67-71$.

Whiteley AS, Thomson B, Lueders T, Manefield M. (2007). RNA stable-isotope probing. Nat Protocols 2: 838-844.

Zhang K, Martiny AC, Reppas NB, Barry KW, Malek J, Chisholm SW et al. (2006). Sequencing genomes from single cells by polymerase cloning. Nat Biotechnol 24: 680-686. 